Asghar, Mandy and Rowe, Nick (2016)

Reciprocity and critical reflection as the key to social justice in service learning: a case study. Innovations in Education and Teaching International, 54 (2). pp. 117-125.

Downloaded from: http://ray.yorksj.ac.uk/id/eprint/1797/

The version presented here may differ from the published version or version of record. If you intend to cite from the work you are advised to consult the publisher's version: http://www.tandfonline.com/doi/full/10.1080/14703297.2016.1273788

Research at York St John (RaY) is an institutional repository. It supports the principles of open access by making the research outputs of the University available in digital form. Copyright of the items stored in RaY reside with the authors and/or other copyright owners. Users may access full text items free of charge, and may download a copy for private study or non-commercial research. For further reuse terms, see licence terms governing individual outputs. Institutional Repository Policy Statement

\title{
RaY
}

Research at the University of York St John

For more information please contact RaY at ray@yorksj.ac.uk 
Mandy Asghar (corresponding author)

York St John University

Lord Mayors Walk

York YO317EX

01904876823

m.asghar@yorksj.ac.uk

Nick Rowe

York St John University

Lord Mayors Walk

York YO317EX

01904876823

n.rowe@yorksj.ac.uk

Research conducted at York St John University 


\section{Reciprocity and critical reflection as the key to social justice in service learning: a case study}

Mandy Asghar ${ }^{1}$

Academic Development, York St John University, York, United Kingdom

Nick Rowe

Converge, York St John University, York, United Kingdom

Service-learning is experiential education that encourages students as socially responsible and active citizens working in and with members of the community. We consider how these ideas illuminate the ambitions of a unique service-learning opportunity known as 'Converge,' a university partnership with a healthcare provider that brings together students and users of mental health services in a variety of educational activities. We are particularly concerned in this article to address the criticism that service learning can exploit marginalised groups for the benefit of student education. We propose that reciprocal relationships which challenge established ideas and practices, together with engaging students in critical and informed analysis are key components in ensuring that service learning is socially just.

Keywords: service-learning, reciprocity, social justice, relational.

\section{Introduction}

There has been criticism that service-learning primarily benefits students at the expense of the communities with which they engage (Chupp \& Joseph, 2010; Butin, 2010). As such it could potentially be considered exploitative, failing to provide students with a critical appreciation of the issues of power and inequality embedded in working with deprived or marginalised communities. In this paper we argue that if interactions with communities are premised on authentically working together, they require a relational approach underpinned by two key factors: critical reflection and reciprocity. We approach this debate through a case study of a service learning opportunity entitled 'Converge ', a university based project offering educational opportunities to local people who use mental health services. The paper explores how Converge is operationalised within our institution, its

${ }^{1}$ Corresponding author m.asghar@yorksj.ac.uk 
philosophical underpinning and connections to the service-learning literature. We will consider the reciprocal nature of the relationship between university students and people who use mental health services and argue that the presence of this reciprocity is a key component preventing the exploitation of participants and fulfilling a desire for social justice. In doing so we make reference to a snapshot of data from our previously published research (Asghar \& Rowe, 2016 in press; Rowe, Forshaw, \& Alldred, 2013). We will also suggest that a critical awareness of the political and cultural positioning of the work is crucial to non-exploitative practice.

\section{Converge}

Converge is a partnership established in 2008 between a UK university and the local mental health service provider to deliver educational opportunities to people who use mental health services. It offers courses in sports/exercise, music, theatre, dance, fine art, creative writing, film-making, psychology and coaching. University students (hereafter known as students) work alongside people who use mental health services (hereafter known as Converge students). It is important to note that nomenclature is a critical issue in mental health to some extent defining relations of power and identity. Converge has, as a fundamental principle, that it will work with people as primarily students, hence the use of 'Converge student' and 'University student'.

Student engagement in Converge occurs either within existing programmes of study or sometimes as a voluntary activity in three main ways: a) Students co-teach courses, taking a level of responsibility commensurate with their experience and ability. They are involved in planning, delivering and evaluating sessions, usually alongside a university tutor or postgraduate student. They are also asked to support the involvement of participants in whatever way seems appropriate for the individual. For example, students lead theatre, dance and music classes, they teach songs in the choir, or they lead aspects of the sports course.

b) Through a 'student buddy scheme', in which students are trained and then allocated to a Converge student, in order to offer support. For example, students support participants in the choir or they welcome people on to the campus to take part in our courses. 
c) In researching or evaluating aspects of Converge projects. For example, occupational therapy students in their final dissertation investigated participants' perception of the Converge choir.

Converge is driven by two interrelated imperatives. Firstly, the need for recovery-orientated, non-stigmatising educational experiences for people who are experiencing mental health problems. The project invites people to take as full a part in university life as possible. This enables the first step to recovery, 'developing a positive identity outside of being a person with a mental illness' (Slade, 2009, p. 83). The aim is to challenge the dynamics of social exclusion that make it difficult for people who use mental health services to access good quality educational and employment opportunities. The second imperative is to provide opportunities for university students to learn through working alongside people who use mental health services. The aim is to enhance students' employability through 'real world' experiences and to challenge stigmatizing attitudes toward mental illness. The relationship of these two imperatives led to the project's title, the intention being to create a convergence of interests between a mental health provider and a university. This convergence is crucial to the sustainability of the project, since it matches the 'core business' of its key providers - the university educates its students and the health service has access to a valuable provision for its clients. This model of collaboration can make a real difference to the lives of users of mental health services, full-time students and the university community as a whole. Converge can be considered a form of servicelearning through which university students learn by adapting their subject knowledge and skills for a very different audience. As a result of meeting and working alongside people with very different life experiences to their own, students therefore have the opportunity to gain understanding of the political and cultural factors that impact on mental health.

\section{What is service-learning?}

Service-learning, a term more often used in North America and South Africa than in Europe, is a pedagogic approach that specifically encourages students as socially responsible and active citizens to work in and with members of the community. Considered an approach premised on notions of social justice 
and reciprocity (Jacoby, 2015), it has been suggested it should be a discipline in its own right with a structured academic programme (Butin 2010). More pragmatically it is important for an institution to decide which approach best suits their traditions and mission (Jacoby, 2015).

Service-learning is essentially experiential education with the potential to empower the community and address social problems (Marullo \& Edwards, 2000). It therefore promotes student development with the caveat that there is mutual benefit to all involved (Chupp \& Joseph, 2010). Also described as authentic and problem-orientated, service-learning provides opportunities for students to create their own knowledge and apply theory to practice (Butin, 2010). To do so effectively, requires them to engage in meaningful reflection on their experiences (Roskell, White \& Bonner, 2012; Chupp \& Joseph, 2010).

In the early days of service-learning in the US, Giles and Eyler (1994) suggested a need for a theoretical underpinning to help explore service learning in practice. They focused on the philosophy of John Dewey, and his ideas that learning from experience occurs on a continuum, resulting from the interaction between the learner and the environment. Others, since then, (Innes, Gilchrist, Friedman \& Tompkins, 2016; Jacoby, 2015) have drawn on Dewey's concept of participatory democracy where meaningful dialogue is seen to be the critical factor for successful partnerships between universities and the communities they work with. Giles and Eyler (1994) concluded by positing nine possible areas from which a theory of service-learning could be developed. Under each, questions and problems were proposed to stimulate further exploration and identify potential relationships between various types of service learning experiences and its impact. These areas included the role of reflection, how learning occurs through inquiry, the nature of community interaction, and development of democracy and citizenship. Twenty years on, the debate continues fuelled by new evidence from extensive service learning research, a recognition that context is extremely important, and that the complexity of service learning presents many challenges (Jacoby, 2015).

Converge began with a simple, if perhaps naïve, assumption: that real benefit would come to university students through adapting and sharing their subject knowledge with local people who use mental health services. Butin's (2010) four orientations towards service learning have proved retrospectively 
a valuable way of conceptualising the challenges and opportunities the project has encountered. The technical perspective focuses on 'the efficacy, quality, efficiency and sustainability' (Butin, 2010, p.8) of process and outcome as a means to standardize students' learning and their experience. The complex engagement of students in theatre, dance, music and more conventional learning settings have proved difficult to standardise and it has been a challenge to achieve parity with those not involved in Converge. Butin's cultural perspective has raised questions for us about how we might increase the students' tolerance of difference and the university's relationship with the mental health community. His political perspective in service learning emphasises how power may be at work in students' engagement with marginalized social groups and we have been keen to increase the students' awareness of this concern in their own practice. Finally, his antifoundational perspective, which encourages tutors and students to continually question the basis of social engagement, suspend certainty and remain in a state of doubting enquiry has proved a valuable way of summarising our aim (see Rowe, 2015)

In the experience of Converge, service-learning is at its best when it is underpinned with a social justice ethos. Ambitions for the community and university are to work collaboratively to achieve institutional transformation and politicization of students. To facilitate effective and lasting social change, as opposed to solely giving to those in need (Marullo \& Edwards, 2000). Chupp and Joseph (2010) define a social justice approach as the development of values and students' personal sense of social responsibility but they consider this as having short-term impact and more influential for the student than the community. However when institutions work with local communities to instigate applied research and project work, build relationships, create management and support mechanisms, it has greater potential to influence curriculum design and become embedded into the culture of an institution (Chupp \& Joseph, 2010). It is through taking this service-learning approach that Chupp and Joseph suggest has the greatest possibly of promoting institutional change and one where reciprocity is considered fundamental (Jacoby, 2015). Certainly, the experience of Converge suggests that successful service learning projects are ones that are 
sustained and well-organised, promote tolerance of difference, are aware of the inevitable power relations at work and continually throw the practice and its assumptions into question.

\section{The impact of service-learning for students}

Butin (2010, p. 38) suggested that service-learning is 'a wickedly complex problem defying quantitative solutions' and yet the extensive research in this area is dominated by quantitative studies. We have therefore highlighted a snapshot of that research from a variety of methodological perspectives that demonstrates the impact service-learning can have on the student learning.

A mixed methods US study of over 2,200 college undergraduate students, of whom $76 \%$ participated in some form of community service, identified a range of positive benefits for students, including: improved academic performance, self-efficacy and leadership, and a heightened sense of civic responsibility (Astin, Vogelgesang, Ikeda, \& Yee, 2000). It influenced students' subsequent career choice and highlighted the need for reflection and connections to be made between the experiences and course material taught in class. Astin et al (2000) defined community based learning as service learning when students engaged in the activity as part of a course (30\% ) as opposed to the $46 \%$ who engaged in extra-curricular voluntary community activities. The impact in the majority of outcomes was significantly greater for those who engaged as part of a taught course.

Internationally, smaller studies demonstrate similar findings. In a US nursing service-learning project, conducted virtually, students worked with qualified colleagues in rural settings on informatics projects (Fairchild, 2012). Analysis of stakeholder evaluations from a two-year period, found improved teamwork and collaborative skills for the students and the qualified nurses they worked with. Another nursing study, in South Africa (Sindi and Fikile 2013), also concluded that through service-learning, knowledge is constructed collaboratively and requires active learning and scaffolding. Service-learning was used to develop 'caring' in dental and physiotherapy students in the UK. Through a mixed methods investigation (focus groups, questionnaires and interviews), this 'coats off' approach developed students' insights and for physiotherapy students, in particular, enhanced their higher order thinking 
(Roskell et al 2012). Amerson (2010) explored how engagement in national and international community projects influenced the cultural competence of 69 nursing students in the US. Using a transcultural self-efficacy tool, improvement occurred across practical, cognitive and affective domains of cultural competence. Roskell et al (2012) and our own previous research (Rowe et al., 2013) also found that service-learning experiences reduces prejudice and stereotyping behaviour by some students.

Despite the positive outcomes often portrayed, the research raises a number of issues. Some students could not see the point of the experience and had little interest in the psycho-social aspects of health (Roskell et al., 2012), often those drawn to it are already empathetic and caring. This particularly related to the physiotherapy students who failed to see the relevance of engaging in an activity they perceived as not directly related to their professional practice. It has been suggested that it can be difficult to change students' perceptions, as they tend to see what they expect to see, and where change occurs, it is often only temporary (Innes et al., 2016). More perplexing is the suggestion that service-learning can actually reinforce negative views (Chupp \& Joseph 2010). Both of these suppositions have implications for how students should be supported and challenged to reflect on their own unconscious biases and stereotypical behaviours (Innes et al., 2016).

Chupp \& Joseph (2010) expressed concerns about the variety of activities described as service-learning that often serve student needs over that of the community. Traditionally students who engaged in such projects were seen to be white, middle class with high cultural capital helping out those less privileged than themselves (Butin, 2006). However as the demographic of the higher education student population changes, challenges arise when students are expected to engage in service-learning projects in the less privileged communities from which they themselves hail from (Butin, 2006; Jacoby, 2015).

Finally, there can be difficulties in sustaining service-learning due to a reluctance to include it in already packed programmes of study (Roskell et al., 2012), and there is evidence it can be negatively influenced by budgetary constraints when funding is tight (Butin, 2006). Considering service-learning 
as a pedagogic approach, could help overcome this challenge, so that it is not seen as just another thing to add to the curriculum. This has been our ambition and over time increasing numbers of programme areas are finding ways to integrate student learning opportunities with Converge projects. Important too is the institutional commitment to the underpinning rationale for embracing service-learning and how that should play out in the way in which it is enacted. For us this means considering how Converge is premised on a relational approach creating opportunities for university students to engage in a critically reflective and reciprocal manner with Converge students.

\section{Reciprocity}

Dostillo et al. (2012) regard reciprocity as 'a foundational concept in service learning' (p.18). It can be defined as adherence to principles of 'respect, trust, genuine commitment, balancing power, sharing resources and clear communication' (Jacoby, 2015, p. 247). As with social justice, reciprocity is an important, yet debated element of effective service-learning (Dostilio et al., 2012, Jacoby, 2015). Depending on definition, it has the potential for different consequences for an institution, the students engaging in it and the community within which they work. In an effort to establish consensus of meaning employed across the service-learning literature, Dostilio et al. (2012) carried out a concept review. In conclusion they proposed three orientations towards reciprocity: exchange, influence, and generatively-orientated reciprocity. We previously explored the impact of Converge on students' perceptions of mental health care users (Rowe et al., 2013) and on student learning (Asghar \& Rowe, in press 2016). As reciprocity seems key to the success of service learning initiatives we felt it was therefore important to explore our previous research findings for relevant evidence.

\section{Methodology}

Both studies (Rowe et al., 2013, Asghar \& Rowe, in press 2016) had adopted qualitative methodologies to capture the lived experience of students through a series of semi-structured interviews. The majority were interviewed both before and after they had participated in a number of Converge projects. This helped us understand how their perceptions changed as they became more 
involved in Converge activities. Five students in Rowe et al (2013) and six in Asghar and Rowe (in press 2016) provided rich descriptions of their experiences. The data in each study was independently analysed by the researchers, followed by discussions to share and compare findings, prior to establishing final themes. For this paper we revisited the data from both studies for evidence of reciprocity in action which we have used to illuminate each of the three orientations as follows.

\section{Findings}

In the exchange orientation, reciprocity is characterised by 'an interchange of benefits, resources and actions' (p.19). This is about a simple exchange that benefits but does not fundamentally change both partners. In relation to Converge, university students share their subject knowledge; learn teaching and facilitation skills, while Converge students/participants bring life experience and insights new to students. As one university student said: 'We had our ideas and they had theirs. We were bouncing off each other.' A Converge student told us: 'They can learn from us and we can learn from them ... it's a two-way thing.'

Influence orientated reciprocity is characterised by the relational connections between personal, social and environmental elements and the 'influence this has on the process and/or outcome of the collaboration' (p.19). Processes and approaches are influenced by the participants' 'ways of knowing and doing' (p.19). University students were often concerned about how they would be accepted by Converge students and it was clear in our interviews, after their experiences, the surprise and pleasure they had at being able to become part of this community where everything was shared. Converge students make works of art, compose pieces of music and theatre, and contribute ideas that influence student learning. The university community is influenced by the presence of people with very different life experiences and mental health service providers benefit from the different approaches and worldviews a university brings. 
$X$ wasn't really a teacher as such, we were all in a collective... we were all equal... it was nice to feel together ... I just want to be with them in their community. (University student)

I was really scared I was going to offend people... scared the group wouldn't take to me. I got into the group and they were really welcoming...my ideas were valued (University student)

Through Generativity-orientated reciprocity participants or collaborators 'produce something new together that would not otherwise exist.' (p.19) Through this process a change is effected in what collaborators do and, more radically, in who they are. The daily presence of Converge students and activities in the university presented challenges to the institution requiring it to revaluate the purpose of a university and attitudes to mental illness. It can also change teaching practices: one tutor, commenting on a psychology class she runs in Converge said:

It's a joint construction between you and the group, it's not that you can go in and deliver the same course and it will always be the same, you have to let it lead itself or decide the direction people are interested in.

In a vivid illustration of generativity-orientated reciprocity a Converge student regards the presence of university students in her singing class in the following way:

...somehow it reframes your illness into an illness on a spectrum of illness... it puts you on the same scale, side by side, and makes it then seem something that you can overcome by shifting up or down that scale.

Converge seeks to have an impact at the student, community and institutional levels. Only by working across these groups can such ventures ensure social justice rather than merely offering charitable activities that tend to reinforce existing power relations. The ambition is to achieve 'thick, generative-oriented reciprocity, where power is shared and knowledge created through joint construction, promoting a collaborative approach to 
learning and growth' (Jaeger, 2011, cited in Jacoby, 2015). It may be that this type of reciprocity is a key characteristic of the success of the Converge experience for both university and Converge students

\section{Critical Reflection}

One of the key criticisms of service-learning is that it can exploit marginalized groups, perpetuate community problems or fail to move beyond an approach more reminiscent of charity work, where primarily the students benefit (Marullo \& Edwards, 2000). To achieve lasting value for all, there must be a willingness to develop collaborations over time and to continually reflect on the impact on the institution as a whole, the students and the community. Converge aims to make the privileges and pleasures of higher education accessible to people who are often marginalised from mainstream society. It seeks to align with Butin's political perspective 'where the personal and the political meet in a substantive practice and where higher education is viewed as a central agent of change for an equitable society' (2010, p.135). Converge aims to support students to be participatory and justice-oriented citizens, providing space for them to examine the political, cultural, economic and historical circumstances of those who have the lived experience of mental ill health. We are painfully aware that such ambitious aims often fall short and that it is easy for disempowering practices to be replicated. A university is not immune from pervasive stigmatising attitudes towards mental illness. Without critical reflection there is danger of service-learning being an exploitative practice (Butin, 2010; Jacoby, 2015). It can reinforce inequality, create 'learning laboratories' for students which offer little to those they work with. Where it is effective reflection stimulates learning that occurs in collaboration with community participants. Students need to be encouraged 'to examine axes of power and privilege across social boundaries' (Weiner, p. 323). In Converge students are encouraged to 'see beyond surface causes' (Westheimer \& Kahn, 2004, p. 2) focusing on some of the following considerations:

- A recognition of the damaging and corrosive nature of the mental health identity, one that can overshadow other possible selves, leaving a person socially isolated and with limited hope for the future. 
- An assumption that personal change will come within the context of community and institutional change and that mental health problems are often systemic and products of oppressive social structures and relationships.

- The potential of education to transform lives and how the identity of 'student' can liberate and open up the possibility for change, and also an awareness of a contradictory truth that education can be oppressive, limiting possibilities and reinforcing hierarchies.

- An understanding of the importance of place - that institutions, which are valued by society convey that value to the individual, promoting self-belief and self-respect.

Of course, a change to students' perceptions of themselves, and of others, takes time, as Baxter Magolda (2004), in her 17-year study of learner development, showed. The ultimate goal is that students achieve selfauthorship (Baxter Magolda, 2004, p.8). At the heart of this is effective citizenship and intercultural maturity, Often students in the early stages of a service-learning project take things at face value and/or believe in the certainty of knowledge, interacting without due consideration of others' values, beliefs and experiences. At a mature level they are open to challenge, appreciate differing world-views and can interact interdependently with others while having a strong sense of self and of the contribution they can make to society (King \& Baxter-Magolda, 2005). Butin (2010) advocates that for students to acquire such maturity, service-learning needs to be 'technical' and 'antifoundational' - technical in providing real-world, authentic experiences, antifoundational by creating opportunities through unsettling pedagogies that prompt students to question their personal perceptions of justice, values and diversity. Just exposing students to those who are different or raising awareness of diversity is insufficient. Students need to develop genuine relationships to be able to engage in meaningful dialogue (Innes et al., 2016).

Service-learning opportunities such as the Converge project, where students are working with, and relating to, diverse community groups, provides learning experiences that can assist in the development of effective citizenship. As a pedagogic approach, it provides opportunities to develop 
students' intercultural maturity through placing them in authentic situations with others who are unfamiliar. Creating opportunities where students experience problems that cause disequilibrium and which they subsequently work through in inquiry with those who are unfamiliar have been identified as the means to promote students development (Asghar \& Rowe, in press 2016; Innes et al., 2016).We do not claim that Converge-like single opportunities alone will achieve this lofty ambition for students, but that service-learning opportunities embedded throughout a curriculum can cumulatively make a difference.

This focus on critical reflection is, we think, a key component in ensuring that service learning does not become a 'charitable exercise' replicating and reinforcing oppressive and stigmatising practices in mental health. We provide opportunities for this through taught modules in which Converge practice forms a part, mental health awareness courses for all university students and through regular supervision opportunities with Converge staff.

\section{Conclusion}

Butin (2010) considers Stanley Fish's critique of such socially-orientated practices. Fish argues that the focus on social engagement deflects universities from their prime purpose: producing critical thinkers. Butin asserts, rightly in our view, that service-learning which encourages reflection and 'fosters a state of doubt' (2010, p. 135) in students, is precisely the kind of experience likely to promote the critical thinking called for by Fish. Converge, if it is to avoid reinforcing inequalities, needs to energetically encourage students to question the social injustices in mental health. Our aspiration therefore is to create opportunities that encourage an antifoundational approach. One which through its action and scholarship throws into question the assumptions and practices that currently operate, in Converge's case, mental health.

A service-learning approach such as the one offered by Converge presents a significant challenge: how can we offer university students the opportunity to work alongside people who use mental health services without reinforcing oppressive, stigmatising practices? We have argued that critical reflection and generativity-orientated reciprocity are crucial factors in squaring 
this circle. Students need to be aware of the cultural, historical and political dynamics at work in any community practice and the university needs to recognise that sustained service-learning will bring change to the institution, its practices and its beliefs.

\section{References}

Asghar, M., \& Rowe, N. (2016, in press). Learning from the unfamiliar: How does working with people who use mental health services impact on students' learning and development? Journal of Further and Higher Education. Amerson, R. (2010). The Impact of Service-Learning on Cultural Competence. Nurse Education Perspectives. 31(1), 18-22.

Astin, A., Vogelgesang, L., Ikeda, E., \& Yee, J. (2000). How service-learning affects students. Higher Education Research Institute, University of California, Los Angeles.

Baxter Magolda, M. in Baxter Magolda, M. \& King, P. (2004) Learning Partnerships. Theory and models of practice to educate for self-authorship. Sterling. 1-37. Virginia: Stylus Publishing.

Butin, D. (2006). The Limits of Service-Learning in Higher Education. The Review of Higher Education. 29(4), 473-498.

Butin, D. (2010). Service-Learning in theory and practice. The Future of Community Engagement in Higher Education. New York: Palgrave Macmillan. Chupp, M., \& Joseph, M. (2010). Getting the most out of service-learning: maximising student, university and community impact. Journal of Community Practice. 18(2), 190-212.

Dostilio, L., Brackmann, S., Edwards, K., Harrison, B., Kliewer, B., \& Clayton, P. (2012). Reciprocity: Saying what we mean and meaning what we say. Michigan Journal of service-learning, Fall, 17-32.

Fairchild, R. (2012). Hold That Tiger! A Collaborative Service-Learning Academic-Practice Partnership with Rural Healthcare Facilities. Nurse Educator. 37(3), 108-114. 
Giles, D., \& Eyler, J.(1994). The Theoretical Roots of Service-Learning in John Dewey: Toward a Theory of Service-Learning. Service Learning, General. Paper 150. http://digitalcommons.unomaha.edu/slceslgen/150 Innes, R., Gilchrist, L., Friedman, S.,\& Tompkins, K. (2016). John Dewey, Participatory Democracy, and University-Community Partnerships in Barnes, S. Brinkley-Rubinstein, Doykos, B. Martin, N. and McGuire, A. Academics in Action. New York, p27-48. Fordham University Press.

Jacoby, B. (2015) Service-Learning Essentials. San Francisco. Jossey-Bass King, P., \& Baxter-Magolda, M. (2005). A Developmental Model of Intercultural Maturity. Journal of College Student Development. 46 (6), 571592.

Marullo, S.,\& Edwards, B. (2000). From charity to justice: The potential of university-community collaboration for social change. American Behavioral Scientist. 3 (5), 895-912.

Roskell, C., White, D., \& Boner, C. (2012). Developing patient-centred care in health professionals: reflections on introducing service-learning into the curriculum. International Journal of Therapy and Rehabilitation. 19(8), 448456.

Rowe, N., N. Forshaw and G. Alldred. 2013. A return to ordinariness: How does working alongside people who use mental health service effect theatre students' attitudes to mental illness? Journal of Applied Arts and Health. 4 (2), 151-162.

Rowe, N. (2015). Creating a Healing Campus: A Partnership between a University and a Provider of Mental Health Services. University Partnerships for Community and School System Development. (Vol. 5, pp. 119-134). Online: Emerald Insight.

Sindi, M., \& Fikile, M. (2013). Conceptualisation of knowledge construction in community service-learning programmes in nursing education. Curationis Journal of the Democratic Nursing Organisation of South Africa. 36(1) 1-10. doi.org/10.4102/curationis.v36i1.69 Slade, M. (2009). Personal recovery and mental illness: A guide for mental health professionals. Cambridge: Cambridge University Press. 
Weiner, D. (2015) Across Boundaries of Privilege: Service-Learning for Social Justice in Jagla, V., Furco, A., \& Strait, J., Service-Learning Pedagogy. How does it measure up? 323-340. Information Age Publishing. Westheimer, J., \& Kahn, J. (2004). Educating the 'Good' Citizen: Political Choices and Pedagogical Goals. Political Science and Politics. 2, 241-247.

Mandy Asghar is Associate Professor and Director of Academic Development. Her research focuses on formative assessment and the use of dialogue as a learning tool for staff and students. She is particularly interested in the concept of relational pedagogy.

Nick Rowe is Associate Professor and Director of Converge. He has a background as a psychiatric nurse and drama therapist. He is particularly interested in arts and health research and practice. 